УДК 616.314-002-08:616.441-006.5]-053.2

DOI

(СН. Б. Кузняк, О. І. Годованець

ВДНЗ України «Буковинський державний медичний університет», м. Чернівці

\title{
Лікування карієсу зубів у дітей із дифузним нетоксичним 3обом
}

Резюме. Застосування препаратів макроелементів та мікроелементів на фоні базової йодотерапії у дітей із дифузним нетоксичним зобом дозволяє стабілізувати показники інтенсивності карієсу зубів, підвищити рівень стоматологічного здоров’я та запобігти розвитку можливих ускладнень із боку зубощелепної системи й організму дитини в цілому.

Ключові слова: діти, карієс, дифузний нетоксичний зоб, метод лікування.

\section{Н. Б. Кузняк, О. И. Годованец}

ВГУЗ Украины «Буковинский государственный медицинский университет», г. Черновцы

\section{Лечение кариеса зубов у детей с диффузным нетоксическим зобом}

Резюме. Применение препаратов макроэлементов и микроэлементов на фоне базовой йодотерапии у детей с диффузным нетоксическим зобом позволяет стабилизировать показатели интенсивности кариеса зубов, повысить уровень стоматологического здоровья и предотвратить развитие возможных осложнений со стороны зубочелюстной системы и организма ребенка в целом.

Ключевые слова: дети, кариес, диффузный нетоксический зоб, метод лечения.

\author{
N. B. Kuzniak, O. I. Hodovanets
}

HSEI of Ukraine «Bukovynian State Medical University», Chernivtsi

\section{Treatment of dental caries in children with diffuse nontoxic goiter}

Summary. The use of macro- and trace elements-containing medicines against the basic iodine therapy in children with diffuse nontoxic goiter enables to make the indices of dental caries intensity stable, to improve the level of dental health and prevent the development of possible complications from the site of the maxillodental system and the body of a child as the whole.

Key words: children, caries, diffuse nontoxic goiter, method of treatment.

Вступ. Аналіз літературних даних показав, що розвиток як зобної ендемії, так і ендемії карієсу, окрім дефіциту йоду та фтору, може бути зумовлений дисбалан- сом інших мікроелементів. У регуляції гормональної функції щитоподібної залози певна роль належить селену, купруму, мангану, цинку, кобальту тощо, що 
зумовлює особливості йодного обміну та його зміни в різних геохімічних умовах [3, 5-9].

Каріозний процес також надзвичайно чутливий до мікроелементного забезпечення організму. Доведено вплив окремих мікронутрієнтів на процеси ре- та демінералізації емалі зубів та формування кісткової маси. До них належать есенціальні мікроелементи - купрум, цинк, манган, ферум, а також умовно есенціальні - бор, фтор, кремній $[1,2,4,8,10]$.

Однак дані щодо впливу тих чи інших мікроелементів на функціонування тканин ротової порожнини, їх роль у розвитку стоматологічної патології та можливості використання для корекції метаболічних порушень залишаються недостатньо висвітленими.

Метою дослідження було обгрунтувати доцільність застосування препаратів макро- та мікроелементів у комплексі лікування карієсу зубів у дітей, які страждають від дифузного нетоксичного зоба.

Матеріали і методи. 3 метою оцінки ефективності нового методу лікування під нашим спостереженням протягом двох років знаходились 120 дітей віком 6-7 та 12 років із дифузним нетоксичним зобом та карієсом. Розподіл на групи: групи порівняння (контролю), яким здійснювали загальноприйняті заходи із лікуваннякарієсузубів тайогоускладнень, та групи спостереження, дітям якої додатково проводили ряд лікувальнопрофілактичних заходів. Зокрема, гігієнічний догляд за ротовою порожниною здійснювали 3 використанням паст «R.O.C.S. Teens», до складу яких входять амінофторид та ксиліт. Також для догляду заротовоюпорожниноювикористовували ополіскувач «R.O.C.S. Teens», що містить екстракт ламінарії, ксиліт, кальцію гліцерофосфат та магнію хлорид. Загальне лікування включало комплексний вітамінно-мінеральний препарат, до складу якого входять кальцій та основні есенціальні мікроелементи, препарат калію йодиду. Як вітамінно-мінеральний препарат застосовується «Кальцемін адванс» по 1 таблетці 1 раз на добу під час прийому їжі протягом 1 місяця 2 рази на рік. Обов'язковим був прийом препарату калію йодиду під контролем ендокринолога. Дозування препарату залежно від віку дитини: 6-12 років - по 100 мкг на добу, 12-15 років - по 150 мкг на добу.

Стан твердих тканин зуба оцінювали за загальноприйнятими методиками із застосуванням об'єктивних та суб'єктивних методів обстеження: скарги, збір анамнезу, огляд, інструментальне дослідження, визначення індексу карієсу КПВ.

Статистичну обробку даних проведено методом варіаційної статистики 3 використанням критерію Стьюдента за допомогою комп’ютерної програми STATISTICA 6.

Результати досліджень та їх обговорення. Попередньо проведені нами клініко-параклінічні обстеження дітей із дифузним нетоксичним зобом показали зниження рівня основних мінералізувальних компонентів ротової рідини: іонів кальцію, фосфат-іонів та інактивацію ферменту лужної фосфатази, що вказує на порушення процесу мінералізації емалі. При патології щитоподібної залози в твердих тканинах зуба встановлено недостатність мікроелементів, зокрема цинку, купруму, феруму, що патогенетично посилює процеси демінералізації та клінічно призводить до декомпенсованих форм карієсу та його ускладнень. Це обгрунтовує необхідність застосування препаратів макро- та мікроелементів для нормалізації обмінних процесів в емалі як на локальному рівні, так і на рівні всього організму.

Метод лікування, запропонований нами, було використано у дітей двох вікових груп: 6-7 та 12 років. Результати моніторингу за дітьми груп дослідження представлено в таблицях 1 та 2.

Інтенсивність карієсу зубів у обстежених дітей віком 6-7 років становила 0,830,87 . У дітей групи спостереження не було зростання даного показника протягом року. Через два роки відбувся приріст інтенсивності карієсу зубів у межах 0,03 $\pm 0,002$. Натомість у групі порівняння через піврокувстановленозбільшення кількості уражених зубів, а також наявність нових ускладнень каріозного процесу.

Індекс КПВ у 12-річних дітей із дифузним нетоксичним зобом на момент початку 
таблищя 1. Результати клінічного спостереження за дітьми віком 6-7 років у динаміці лікування

\begin{tabular}{|l|c|c|c|c|}
\hline \multirow{2}{*}{} & \multicolumn{2}{|c|}{ Інтенсивність карієсу, КПВ } & \multicolumn{2}{|c|}{ Ускладнення карієсу } \\
\cline { 2 - 5 } & $\begin{array}{c}\text { група спостере- } \\
\text { ження } \\
(\mathrm{n}=30)\end{array}$ & $\begin{array}{c}\text { група конт- } \\
\text { ролю } \\
(\mathrm{n}=30)\end{array}$ & $\begin{array}{c}\text { група спостере- } \\
\text { ження } \\
(\mathrm{n}=30), \%\end{array}$ & $\begin{array}{c}\text { група конт- } \\
\text { ролю } \\
(\mathrm{n}=30), \%\end{array}$ \\
\hline До лікування & $0,87 \pm 0,07$ & $0,83 \pm 0,06$ & 3,33 & 3,33 \\
\hline Після лікування & $0,87 \pm 0,07$ & $0,83 \pm 0,06$ & 3,33 & 3,33 \\
\hline Через півроку після лікування & $0,87 \pm 0,07$ & $0,93 \pm 0,07$ & 3,33 & 6,67 \\
\hline Через рік після лікування & $0,87 \pm 0,07$ & $1,07 \pm 0,12$ & 3,33 & $6,67 * *$ \\
\hline Через два роки після лікування & $0,90 \pm 0,07$ & $1,17 \pm 0,19 *, * *$ & 3,33 & $13,33^{*}, * *$ \\
\hline
\end{tabular}

Примітки: 1) * - вірогідна відмінність показників до лікування та після лікування, $<<0,05$; 2) ** - вірогідна відмінність показників груп спостереження та контролю, p<0,05.

таблиия 2. Результати клінічного спостереження за дітьми віком 12 років у динаміці лікування

\begin{tabular}{|l|c|c|c|c|}
\hline \multirow{2}{*}{} & \multicolumn{2}{|c|}{ Інтенсивність карієсу, КПВ } & \multicolumn{2}{|c|}{ Ускладнення карієсу } \\
\cline { 2 - 5 } & $\begin{array}{c}\text { група } \\
\text { спостереження } \\
(\mathrm{n}=30)\end{array}$ & $\begin{array}{c}\text { група } \\
\text { контролю } \\
(\mathrm{n}=30)\end{array}$ & $\begin{array}{c}\text { група } \\
\text { спостереження } \\
(\mathrm{n}=30), \%\end{array}$ & $\begin{array}{c}\text { група } \\
\text { контролю } \\
(\mathrm{n}=30), \%\end{array}$ \\
\hline До лікування & $4,2 \pm 0,37$ & $4,0 \pm 0,28$ & 50,0 & 50,0 \\
\hline Після лікування & $4,1 \pm 0,35$ & $4,0 \pm 0,28$ & 41,7 & 50,0 \\
\hline Через півроку після лікування & $4,2 \pm 0,37$ & $4,3 \pm 0,26$ & 41,7 & 58,3 \\
\hline Через рік після лікування & $4,2 \pm 0,37$ & $4,7 \pm 0,31$ & 41,7 & $58,3^{* *}$ \\
\hline Через два роки після лікування & $4,2 \pm 0,37$ & $5,2 \pm 0,49 *, * *$ & 41,7 & $66,7^{*}, * *$ \\
\hline
\end{tabular}

Примітки: 1) * - вірогідна відмінність показників до лікування та після лікування, $р<0,05$; 2) ** - вірогідна відмінність показників груп спостереження та контролю, p<0,05.

лікування був у межах 4,0-4,2. Упродовж двох років не спостерігали зростання показників інтенсивності карієсу зубів у дітей групи спостереження, натомість у групі порівняння встановлено чітку динаміку до підвищення даних показників.

У половини обстежених до лікування реєстрували ті чи інші нозологічні форми пульпіту та періодонтиту постійних зубів. У всіх дітей переважали хронічні форми запалення пульпи та періодонта. Після медикаментозної корекції, запропонованої нами, скоротилася кількість нових ускладнень, що вказує на зростання карієсрезистентності твердих тканинах зубів у дітей.

Таким чином, застосування препаратів макроелементів та мікроелементів на фоні базової йодотерапії в дітей із дифузним нетоксичним зобом дозволяє стабілізува- ти показники інтенсивності карієсу зубів, підвищити рівень стоматологічного здоров'я та запобігти розвитку можливих ускладнень з боку зубощелепної системи й організму дитини в цілому.

Висновки. Постійнодіючий фактор дефіциту ряду життєво важливих мікронутрієнтів в організмі дитини зумовлює необхідність тривалої дотаційної терапії, щонайменше до закінчення формування дитячого організму в цілому та емалі зубів зокрема. Кратність проведення курсів - 1-2 рази на рік залежно від ступеня тяжкості стоматологічної та соматичної патологій.

Перспективою подальших досліджень $€$ вивчення впливу препаратів макро- та мікроелементів на обмінні процеси у твердих тканинах зуба при тиреопатології в дітей. 


\section{Дитяча стоматологія}

\section{Список літератури}

1. Колесник К. А. Особенности костного метаболизма у детей с зубочелюстными аномалиями и сопутствующим диффузным нетоксическим 30бом / К. А. Колесник, Н. Н. Каладзе, О. В. Деньга // Вісник стоматології. - 2013. - № 2. - С. 74-80.

2. Оберлис Д. Биологическая роль макро- и микроэлементов у человека и животных / Д. Оберлис, Б. Харланд, А. Скальный. - СПб. : Наука, 2008. - 544 с.

3. Рустембекова С. А. Элементный дисбаланс при патологии щитовидной железы / С. А. Рустембекова, А. С. Аметов, А. М. Тлиашинова // РМЖ. 2008. - № 16. - С. 1078-1081.

4. Скальный А. В. Биоэлементы в медицине / А. В. Скальный, И. А. Рудаков. - М. : ОНИКС 21 век, 2004. -272 с.

5. Участь мікроелементів та вітамінів у розвитку дифузного нетоксичного зоба у підлітків, які мешкають в умовах легкого йододефіциту / O. I. Плехова, Д. А. Кашкалда, С. I. Турчина, Ю. В. Волкова // Ендокринологія. - 2014. - № 4. C. $335-336$.
6. Determination of cadmium, cobalt, copper, iron, manganese, and zinc in thyroid glands of patients with diagnosed nodular goitre using ion chromatography / A. Blazewicz, W. Dolliver, S. Sivsammye [et al.] // J. Chromatogr. B. Analyt. Technol. Biomed. Life Sci. 2010. - Vol. 878(1). - P. 34-38.

7. Evaluation of iron in serum and urine and their relation with thyroid function in female goitrous patients / G. A. Kandhro, T. G. Kazi, H. I. Afridi [et al.] // Biol. Trace Elem. Res. - 2008. - Vol. 125. - P. 203-212.

8. Jarup L. Cadmium and averse effects human health/ L. Jarup // Indian J Med Res. - 2008. - Vol. 128. P. 557-564.

9. Selenium status, thyroid volume, and multiple nodule formation in an area with mild iodine deficiency / L. B. Rasmussen, L. Schomburg, J. Kohrle et al. // Eur. J. Endocrinol. - 2011. - Vol. 164(4). P. 585-590.

10. Zinc and human health: an update / C. T. Chasapis, A. C. Loutsidou, C. A. Spiliopoulou [et al.] // Arch. Toxicol. - 2012. - Vol. 86( 4). - P. 521-534.

Отримано 30.10 .15 